\title{
Change in quality characteristics of yellow paprika according to drying methods
}

\author{
Hyeon-A jung, Ju-Yeon Hong* \\ Faculty of Herbal Food Cuisine and Nutrition, Daegu Haany University, Gyeongsan 38610, Korea
}

\section{건조방법을 달리한 노란 파프리카의 품질특성 변화}

\author{
정현아 · 홍주연* \\ 대구한의대학교 한방식품조리영양학부
}

\begin{abstract}
The study attempted to investigate the variation in the quality of the yellow paprika according to the duration of the yellow paprika and to use the basic materials for the development of various processed foods. The moisture content of dried paprika was $\mathbf{1 1 . 1 9 \%}$ on the freeze-drying paprika (FD), and the amount of water was increased by $18.19 \%$ on the 15 th day of the storage cycle. The $\mathrm{pH}$ has been significantly changed depending on the length of the storage period, and the sugar content in FD. The acidity contents was increased during storage in all dried paprikas showed the highest acidity, but hot air-drying paprika(HAD) was lowest in the acidity. The $L$ value was decreased during storage period from the paprika outside and inside. The a value was not significantly dependent on the length of storage period from paprika outside and inside, and the b value increased the during storage period from paprika outside and inside. The texture of strongness, hardness, chewiness, and brittleness were decreased during storage period from all drying paprika except for FD, showing the increasing trend in cohesiveness, springiness, chewiness, and brittleness. The total aerobes changes was the lowest in HAD.
\end{abstract}

Key words : yellow paprika, hot air-drying, cold air-drying, freeze-drying, quality characteristics

\section{서 론}

최근 건강에 대한 관심과 먹거리를 통한 웰빙이 대세로 여겨지면서 딸기, 토마토, 파프리카 등과 같은 기능성 농산 물의 구매가 늘어나고 있다(1). 파프리카는 1990년대에 고 부가가치 수출 작물로 국내에 도입되어 그간 안정적인 수출 로 채소류 중 고소득 작물이라는 인식이 확산되면서 농산물 단일품목으로는 수출액이 가장 큰 작물이며 국내에서도 파프리카의 소비량이 계속 증가하고 있는데 주로 생것 형태 로 소비되고 있지만 향후 다양한 가공품의 개발로 가격 안정화 및 소비 확대를 기대하고 있는 실정이다(2).

*Corresponding author. E-mail : pinkpunk@dhu.ac.kr Phone : 82-53-819-1426, Fax : 82-53-819-1494

Received 13 November 2017; Revised 19 December 2017; Accepted 20 December 2017.

Copyright (c) The Korean Society of Food Preservation. All rights reserved. 파프리카(paprika, Capsicum annuum L)는 가지과(Solanaceae), 고추속(Capsicum), 고추종(Annuum)에 속하는 한해살이 식 물이며, 파프리카란 말은 어원이 희랍어로 현재 유럽에서 모든 고추를 통칭하고 있으며, 나라에 따라 sweet pepper, pimento, paprika 등으로 불리고 있다 $(3,4)$. 우리나라에서는 매운맛이 없는 bell type의 고추(단고추)를 파프리카라고 하고 있으며 빨간색, 주황색, 노란색, 자주색, 백색 등 다양 한 색상을 가지고 있다(5). 파프리카는 수확 직후에 chlorophyll, carotene, vitamin $\mathrm{A}$ 와 $\mathrm{C}$ 의 함량이 높고 단맛이 강하여 샐러 드나 볶음요리에 주로 사용된다 $(6,7)$. 최근에서는 파프리카 색상에 따라 다양한 카로티노이드가 존재하며 이들로 인해 항산화능에 효과가 있고, 파프리카가 면역력을 높이고 발 암억제 효과가 있다는 것이 알려지면서 국내 소비가 크게 늘어나고 있다(8-10). 지금까지 파프리카에 대한 연구는 한 국산 파프리카의 품종별 화학성분(11), 생 파프리카와 원적 외선 건조 파프리카 분말의 지질 산화억제 효과(12), 한국산 파프리카를 이용한 주스 및 젤리의 제조 및 특성(13), 파프 
리카 즙을 첨가한 증편의 품질특성(14)과 같이 국내에서 생산되고 있는 파프리카를 이용한 가공품 개발에 관한 연구 는 매우 미흡한 실정이다.

식품의 건조는 미생물과 효소에 의한 부패나 변질을 방 지하고 제품의 저장성 및 수송성을 향상시키며 신제품 개발 에 있어서도 다양하게 이용되고 있다. 식품을 건조하는 방 법으로는 비교적 간단한 천일건조와 열풍건조, 냉풍건조가 있고, 산업의 발전으로 인해 진공·동결건조, 원적외선, 마이 크로파방법 등으로 여러 가지 제품이 개발되고 있다(15). 열풍건조는 건조시간이 빠르고 경제적이며 식품이 균일하 게 건조가 되지만 열로 인한 수분손실로 식품이 수축되고 표면이 경화되는 현상과 갈변화로 인해 영양가 저하와 색 상, 맛, 텍스처 등의 문제점이 발생된다고 보고되었다(16). 냉풍건조는 냉풍과 제습을 이용한 건조방법으로 식품의 색과 향, 맛을 그대로 유지 할 수 있다는 장점이 있지만 건조를 하는 시간이 길다는 것이 단점이다(17). 동결건조는 건조된 제품의 물성, 향 및 영양성분의 변화가 적고 건조식 품의 재수화율이 높아서 제품의 품질이 우수한 장점이 있으 나 시설 및 건조 비용이 많다는 것이 단점이다(18).

따라서 본 연구는 향후 소비가 더욱 증가될 것으로 예상 되는 노란 파프리카의 식품 건조 방법을 달리하여 저장기간 에 따른 품질특성 변화를 연구하고, 노란 파프리카의 다양 한 가공식품 개발 및 건강식품 개발의 가능성을 제시하고 기초 자료로 활용하고자 한다.

\section{재료 및 방법}

\section{실험재료}

본 실험에 사용한 재료는 2017년 일반마트에서 구입한 국내산 노란색 파프리카를 사용하였으며, 노란색 파프리카 는 꼭지를 제거한 후 흐르는 물에 씻어 이물질을 제거하고, 반으로 잘라 속을 제거한 후 가로 $2 \mathrm{~cm}$, 세로 $2 \mathrm{~cm}$ 사각형으 로 자른 뒤 사용하였다.

\section{파프리카의 제조}

건조 파프리카의 제조는 열풍건조는 $50^{\circ} \mathrm{C}$ 로 맞춰진 열풍 건조기(LD-918BH, L'EQUIP, Hwaseong, Korea)에서 수분 함량 $15 \%$ 내외로 맞추기 위해 26시간 동안 열풍건조 하였 다. 냉풍건조는 $30^{\circ} \mathrm{C}$ 로 맞춰진 냉풍건조기(JJ-1000, Junjin e\&c, Gyeongsan, Korea)에서 수분함량 $15 \%$ 내외로 맞추기 위해 72 시간 동안 냉풍건조 하였다. 동결건조는 $-80^{\circ} \mathrm{C}$ 급속 냉동고(MDF-U52V, SANYO, Tokyo, Japan)에서 24시간 급 속냉동 후 $-90^{\circ} \mathrm{C}$ 로 맞춰진 진공동결건조기(FD-8512, ILSHIN, Namyangju, Korea)에서 수분함량 $15 \%$ 내외로 맞추기 위해 43 시간 동결건조 하였다. 건조 파프리카의 $15 \%$ 의 수분함량 을 맞추기 위하여 건조과정을 관찰하였으며, 건조된 파프
리카는 밀봉하여 $20^{\circ} \mathrm{C}$ 배양기(HST 1034, HANBAET ST, Bucheon, Korea)에서 보관하였고, 저장기간은 1 일, 5 일, 10 일, 15 일에 이루어졌다.

\section{수분함량 측정}

건조된 노란색 파프리카의 수분함량은 적외선 수분측정 기(XM 60, Precisa, Dietikon, Switzerland)를 이용하여 3회 반복 측정하여 평균값 \pm 표준편차로 나타내었다.

\section{$\mathrm{pH}$ 측정}

건조된 노란색 파프리카의 $\mathrm{pH}$ 는 시료 $10 \mathrm{~g}$ 과 증류수 $90 \mathrm{~mL}$ 를 혼합하고 Homogenizer (AM-7, NIHONSEIKI KAISHA, Tokyo, Japan)를 이용하여 분쇄 후, 여과지 (Whatman No.4)로 $100 \mathrm{~mL}$ 메스플라스크에 여과 한 뒤, 정용하여 $\mathrm{pH}$ meter(Delta 320, Mettler-Toledo, Cangzhou, China)를 이용하여 3회 반복 측정 후 평균값 \pm 표준편차로 나타내었다.

\section{당도 측정}

건조된 노란색 파프리카의 당도는 시료 $10 \mathrm{~g}$ 과 증류수 $90 \mathrm{~mL}$ 를 혼합하고 Homogenizer(AM-7, NIHONSEIKI KAISHA, Tokyo, Japan)를 이용하여 분쇄 후, 여과지 (Whatman No.4)로 $100 \mathrm{~mL}$ 메스플라스크에 여과 한 뒤, 정용하여 굴절당도계(poket PAL-Patissier, ATAGO, Tokyo, Japan)를 이용하였고, 3회 반복 측정하여 가용성 고형분 함량 $\left({ }^{\circ} \mathrm{Brix}\right)$ 으로 표시하였고, 평균값표준편차로 나타내 었다.

\section{산도 측정}

건조된 노란색 파프리카의 산도는 $\mathrm{AOAC}$ 법(19)에 따라 시료 $10 \mathrm{~g}$ 과 증류수 $90 \mathrm{~mL}$ 를 넣고 homogenizer(AM-7, NIHONSEIKI KAISHA, Tokyo, Japan)를 이용하여 분쇄 후 여과지(Whatman No.4)로 $100 \mathrm{~mL}$ 메스플라스크에 여과한 후 정용한다. 필요한 경우 희석하여 희석한 시료용액 30 $\mathrm{mL}$ 에 1\% phenolphthalein(OCI Company Ltd., Seoul, Korea) 용액을 3-4방울 가하고 시료액을 중화시킬 알칼리 표준용 액 $0.1 \mathrm{~N} \mathrm{NaOH}$ 로 적정하여 유기산의 양을 환산하여 나타내 었다. 3 회 반복 측정하여 평균값 \pm 표준편차로 나타내었다.

Titratable acidity $(\%)=\frac{\mathrm{V} \times \mathrm{F} \times \mathrm{A} \times \mathrm{D}}{\mathrm{S}} \times 100$

$\mathrm{V}$ : $0.1 \mathrm{~N} \mathrm{NaOH}$ 용액의 적정소비량

$\mathrm{F}: 0.1 \mathrm{~N} \mathrm{NaOH}$ 용액의 역가

$\mathrm{A}: 0.1 \mathrm{~N} \mathrm{NaOH}$ 용액 $1 \mathrm{~mL}$ 에 상당하는 유기산의 양 $(\mathrm{g})$

$\mathrm{D}$ : 희석 배수

$\mathrm{S}:$ 시료의 채취량 $(\mathrm{g})$ 
색도 측정

건조된 노란색 파프리카의 색도는 색도 색차계(CM6000, Minoita, Osaka, Japan)를 이용하여 파프리카 내피 (inside)와 외피(surface)의 명도(L, lightness), 적색도(a, redness), 황색도(b, yellowness) 값을 3회 반복 측정하여 평 균값 \pm 표준편차로 나타내었으며, 이때 사용한 표준 백색판 (standard plate)의 L 값은 98.18 , a 값은 $1.61, \mathrm{~b}$ 값은 1.88 이었 다.

\section{물성 측정}

건조된 노란색 파프리카의 물성은 Sun rheometer (COPAC-100П, Sun Scientific, Tokyo, Japan)를 사용하여 측정하였다. 측정조건에서 test type은 mode 21 , distance $15 \mathrm{~mm}$ plunger diameter $300 \%$, adaptor type No.4, table speed $60 \mathrm{~mm} / \mathrm{m}$, load cell(max) $2 \mathrm{~kg}$ 의 조건으로 시료 중심부에 2 회 연속 측정하였을 때 얻어지는 값을 산출하여 강도 (strongness), 경도(hardness), 응집성(cohesiveness), 탄력성 (springiness), 씹음성(chewiness), 깨짐성(brittleness)을 3회 반복 측정하여 평균값 \pm 표준편차로 나타내었다.

\section{미생물 검사}

건조된 노란색 파프리카의 미생물 검사는 시료 $10 \mathrm{~g}$ 을 취한 뒤 멸균수 $90 \mathrm{~mL}$ 를 homogenizer(AM-7, NIHONSEIKI KAISHA, Tokyo, Japan)를 이용하여 1 분간 균질화 시킨 후 시료액을 $1 \mathrm{~mL}$ 취하여 $9 \mathrm{~mL}$ 의 멸균수로 10 배 단계희석 하였다. 시험용액 $1 \mathrm{~mL}$ 와 각 단계 희석액 $1 \mathrm{~mL}$ 를 $3 \mathrm{M}$ petrifilm(PetrifilmTM plate, 3M Co., St. Paul, MN, USA)에 접종하여 $37 \pm 1^{\circ} \mathrm{C}$ 배양기(HB-101M, HANBAEK ST, Bucheon, Korea)에서 24시간 배양시킨 후 $\log \mathrm{CFU} / \mathrm{mL}$ 로 표시하였다.

\section{통계분석}

3회 반복 실험을 통한 모든 결과는 SPSS Program (ver.23.0)을 이용하여 평균 \pm 표준편차를 산출하였고, 차이 비교를 위해 분산분석(one-way ANOVA)을 실행하였다. 분 산분석 차이비교 결과, 유의적인 차이가 있을 경우, $\mathrm{p}<0.05$ 수준에서 Duncan's multiple range test를 실시하여 시료간의 유의성을 검증하였다.

\section{결과 및 고찰}

\section{수분함량 변화}

건조방법을 달리한 노란 파프리카의 저장기간 중 수분함 량 변화에 대한 결과는 Table 1 과 같다. 노란 파프리카 수분 함량은 저장 1 일 차 열풍건조한 파프리카(HADP)에서는 $16.72 \%$, 냉풍건조한 파프리카(CADP)에서 $10.30 \%$, 동결건 조한 파프리카(FDP)에서는 $11.19 \%$ 의 수분함량을 보였다.
저장 5 일 차 수분함량은 $\mathrm{HADP}$ 에서는 $16.42 \%, \mathrm{CADP}$ 에서 $45.03 \%, \mathrm{FDP}$ 에서는 $8.10 \%$ 의 수분함량을 보여 1 일 차에 비해 $\mathrm{HADP}$ 와 $\mathrm{FDP}$ 에서 다소 수분함량은 감소함을 보였고, $\mathrm{CADP}$ 에서는 수분함량이 크게 증가함을 보였다. 저장 10 일 차에서는 $\mathrm{HADP}$ 에서는 $59.69 \%, \mathrm{CADP}$ 에서 $47.06 \%, \mathrm{FDP}$ 에 서는 $21.35 \%$ 의 수분함량을 보였으며, 건조 방법에 따라 모든 건조 노란 파프리카 군은 수분함량이 증가하였다. 저 장 15 일 차 수분함량 변화에서는 $\mathrm{HADP}$ 에서는 $31.85 \%$, $\mathrm{CADP}$ 에서 $34.17 \%, \mathrm{FDP}$ 에서는 $18.19 \%$ 의 수분함량을 보였 고, 저장 10 일 차에 비해 건조방법에 따른 파프리카 모든 군에서 수분함량은 감소함을 보였다. 건조방법에 따른 노 란 파프리카의 저장 기간의 수분함량의 변화는 모든 처리군 에서 유의적 차이가 있었다( $\mathrm{p}<0.001) . \mathrm{HADP}$ 와 CADP에서 는 저장기간동안 수분함량의 변화가 크게 나타났으며, FDP 에서는 다른 군에 비해 저장기간 동안의 수분함량의 변화가 크게 나타나지 않았다. $\mathrm{Kim}$ 등(20)의 건조방법에 따른 브로 콜리 새싹의 수분함량 결과 열풍건조에서 수분함량이 높은 것으로 나타나 유사한 결과를 보였고, Park 등(21)의 건조 방법에 따른 블루베리의 품질 및 생리활성에서 동결건조한 블루베리 수분이 $17.32 \%$ 으로 나타났는데 본 연구에서는 $\mathrm{FDP}$ 가 저장 15 일 차의 경우 수분함량이 $18 \%$ 으로 나타나 다른 파프리카 처리군에 비해 수분함량의 변화가 적어 식품 의 변질 부분에 있어서 가공식품으로서 이용도가 더 높을 것으로 생각된다.

\section{$\mathrm{pH}$ 변화}

건조방법을 달리한 노란 파프리카의 저장기간 중 $\mathrm{pH}$ 변 화에 대한 결과는 Table 2 와 같다. 노란 파프리카의 $\mathrm{pH}$ 는 저장 1 일 차 $\mathrm{HADP}$ 에서는 $5.74, \mathrm{CADP}$ 에서 5.40, $\mathrm{FDP}$ 에서 는 5.19으로 노란 파프리카의 $\mathrm{pH}$ 는 $\mathrm{HADP}>\mathrm{CADP}>\mathrm{FDP}$ 순이었다. 저장 5일 차 $\mathrm{pH}$ 는 $\mathrm{HADP}$ 에서 5.63, $\mathrm{CADP}$ 에서 $5.39, \mathrm{FDP}$ 에서는 5.33의 $\mathrm{pH}$ 를 보여 1 일 차에 비해 $\mathrm{HADP}$ 와 $\mathrm{CADP}$ 에서 $\mathrm{pH}$ 는 다소 감소함을 보였고, $\mathrm{FDP}$ 에서는 $\mathrm{pH}$ 가 증가함을 보였다. 저장 10 일 차에서는 $\mathrm{HADP}$ 에서는 5.14 , $\mathrm{CADP}$ 에서 5.15, $\mathrm{FDP}$ 에서는 5.34의 $\mathrm{pH}$ 를 보였으며, 저장 5 일 차와 유사하게 $\mathrm{HADP}$ 와 $\mathrm{CADP}$ 에서 $\mathrm{pH}$ 는 감소함을 보 였고, $\mathrm{FDP}$ 에서는 $\mathrm{pH}$ 가 다소 증가함을 보였다. 저장 15 일 차 $\mathrm{pH}$ 변화에서는 $\mathrm{HADP}$ 에서는 5.39, $\mathrm{CADP}$ 에서 5.09, $\mathrm{FDP}$ 에서는 5.22 이었으며, 저장 10 일 차에 비해 $\mathrm{HADP}$ 에서는 $\mathrm{pH}$ 가 증가함을 보였고, $\mathrm{CADP}$ 와 $\mathrm{FDP}$ 에서는 $\mathrm{pH}$ 가 감소함 을 보였다. 건조방법에 따른 노란파프리카의 저장기간의 $\mathrm{pH}$ 변화는 모든 처리군에서 유의적 차이가 있었지만 ( $\mathrm{p}<0.001)$ 건조방법에 따른 저장초기 $\mathrm{pH}$ 가 5이었으며, 저장 기간이 길어질수록 저장 15 일의 $\mathrm{pH}$ 의 값도 5 정도 나타나 건조방법을 달리한 노란파프리카의 저장기간에 따른 $\mathrm{pH}$ 변화는 크게 변화가 없는 것으로 보였다. 전체적으로 건조 방법에 따른 노란 파프리카의 모든 군에서 약 $\mathrm{pH}$ 5정도의 
Table 1. Changes in the Moisture content of yellow paprika according to drying methods

\begin{tabular}{|c|c|c|c|c|c|c|}
\hline \multirow{2}{*}{\multicolumn{2}{|c|}{ Samples ${ }^{1)}$}} & \multicolumn{4}{|c|}{ Storage period (day) } & \multirow{2}{*}{ F-value } \\
\hline & & 1 & 5 & 10 & 15 & \\
\hline \multirow{3}{*}{$\begin{array}{l}\text { Moisture } \\
\text { content } \\
(\%)\end{array}$} & HADP & $16.72 \pm 0.55^{\left.\left.2()^{(c)}\right) \mathrm{A} 4\right)}$ & $16.42 \pm 1.32^{\mathrm{cB}}$ & $59.69 \pm 1.41^{\mathrm{aA}}$ & $31.85 \pm 1.45^{\mathrm{bA}}$ & $808.49^{* * *}$ \\
\hline & CADP & $10.30 \pm 1.36^{\mathrm{cB}}$ & $45.03 \pm 1.22^{\mathrm{aA}}$ & $47.06 \pm 0.69^{\mathrm{aB}}$ & $34.17 \pm 1.51^{\mathrm{bA}}$ & $561.09^{* * *}$ \\
\hline & FDP & $11.19 \pm 0.32^{\mathrm{cB}}$ & $8.10 \pm 0.19^{\mathrm{dC}}$ & $21.35 \pm 2.25^{\mathrm{aC}}$ & $18.19 \pm 0.90^{\mathrm{bB}}$ & $74.75^{* * *}$ \\
\hline \multicolumn{2}{|c|}{ F-value } & $47.71^{* * 55)}$ & $1032.04^{* * *}$ & $457.38^{* * *}$ & $129.49^{* * *}$ & \\
\hline
\end{tabular}

${ }^{1)} \mathrm{HADP}$, hot air-drying paprika; CADP, cold air-drying paprika; FDP, freeze-drying paprika.

${ }^{2)}$ All value are expressed as Mean \pm SD of triplicate determinations.

3)a-d Means with different superscript in the same column are significantly different $(\mathrm{p}<0.05)$ by Duncan's multiple range test.

${ }^{4) A-D}$ Means with different superscript in the same row are significantly different $(p<0.05)$ by Duncan's multiple range test.

${ }^{\text {5)** }} \mathrm{p}<0.001$

Table 2. Changes in the $\mathrm{pH}$ of yellow paprika according to drying methods

\begin{tabular}{|c|c|c|c|c|c|c|}
\hline \multicolumn{2}{|c|}{ Samples ${ }^{1)}$} & \multicolumn{4}{|c|}{ Storage period (day) } & \multirow{2}{*}{ F-value } \\
\hline & & 1 & 5 & 10 & 15 & \\
\hline \multirow{3}{*}{$\mathrm{pH}$} & HADP & $5.74 \pm 0.01^{2) \mathrm{a} 3 \mathrm{~A} 4)}$ & $5.63 \pm 0.02^{\mathrm{bA}}$ & $5.14 \pm 0.02^{\mathrm{dA}}$ & $5.39 \pm 0.03^{\mathrm{cA}}$ & $581.58^{\star * *}$ \\
\hline & CADP & $5.40 \pm 0.01^{\mathrm{aB}}$ & $5.39 \pm 0.02^{\mathrm{aB}}$ & $5.15 \pm 0.01^{\mathrm{bA}}$ & $5.09 \pm 0.01^{\mathrm{cC}}$ & $758.97^{* * *}$ \\
\hline & FDP & $5.19 \pm 0.01^{\mathrm{CC}}$ & $5.33 \pm 0.01^{\mathrm{aC}}$ & $5.34 \pm 0.01^{\mathrm{aB}}$ & $5.22 \pm 0.02^{6 \mathrm{~B}}$ & $149.91^{* * *}$ \\
\hline \multicolumn{2}{|c|}{ F-value } & $2628.50^{* * * 5)}$ & $314.23^{* * *}$ & $375.11^{* * *}$ & $193.00^{* * *}$ & \\
\hline
\end{tabular}

${ }^{1)} \mathrm{HADP}$, hot air-drying paprika; CADP, cold air-drying paprika; FDP, freeze-drying paprika.

${ }^{2)}$ All value are expressed as Mean \pm SD of triplicate determinations.

${ }^{3) a-d}$ Means with different superscript in the same column are significantly different $(\mathrm{p}<0.05)$ by Duncan's multiple range test.

${ }^{4) A-D}$ Means with different superscript in the same row are significantly different $(\mathrm{p}<0.05)$ by Duncan's multiple range test.

${ }^{5 * * *} \mathrm{p}<0.001$.

결과를 보여 약산성을 띄고 있었다.

당도 변화

건조방법을 달리한 노란 파프리카의 저장기간 중 당도 변화에 대한 결과는 Table 3 과 같다. 노란 파프리카의 당도 는 저장 1 일 차 $\mathrm{HADP}$ 에서는 $1.30^{\circ} \mathrm{Brix}, \mathrm{CADP}$ 에서 2.00 ${ }^{\circ} \mathrm{Brix}, \mathrm{FDP}$ 에서는 $1.83{ }^{\circ} \mathrm{Brix}$ 으로 노란 파프리카의 당도는 $\mathrm{CADP}>\mathrm{FDP}>\mathrm{HADP}$ 순이었다. 노란 파프리카 저장 5 일 차 당도는 $\mathrm{HADP}$ 에서 $1.80{ }^{\circ} \mathrm{Brix}, \mathrm{CADP}$ 에서 $1.70{ }^{\circ} \mathrm{Brix}$,
$\mathrm{FDP}$ 에서는 $2.43{ }^{\circ} \mathrm{Brix}$ 으로 노란 파프리카의 당도는 FDP $>\mathrm{HADP}>\mathrm{CADP}$ 순이었다. 저장 10 일 차 당도는 $\mathrm{HADP}$ 에 서 $1.13{ }^{\circ} \mathrm{Brix}, \mathrm{CADP}$ 에서 $1.2{ }^{\circ} \mathrm{Brix}, \mathrm{FDP}$ 에서는 $2.20{ }^{\circ} \mathrm{Brix}$ 으로 $\mathrm{FDP}$ 가 $\mathrm{HADP}$ 와 $\mathrm{CADP}$ 보다 당도가 높았다. 저장 15 일 차의 당도는 $\mathrm{HADP}$ 에서 $1.67^{\circ} \mathrm{Brix}, \mathrm{CADP}$ 에서 $1.83{ }^{\circ} \mathrm{Brix}$, $\mathrm{FDP}$ 에서는 $2.87^{\circ} \mathrm{Brix}$ 으로 노란 파프리카의 당도는 FDP $>\mathrm{CADP}>\mathrm{HADP}$ 순으로 동결건조한 파프리카에서 당도가 높았다. 건조방법에 따른 노란 파프리카의 당도변화는 FDP 가 $\mathrm{HADP}$ 와 $\mathrm{CADP}$ 보다 저장 초기보다 저장기간이 길어질

Table 3. Changes in the Brix of yellow paprika according to drying methods

\begin{tabular}{|c|c|c|c|c|c|c|}
\hline \multirow{2}{*}{\multicolumn{2}{|c|}{ Samples ${ }^{1)}$}} & \multicolumn{4}{|c|}{ Storage period (day) } & \multirow{2}{*}{ F-value } \\
\hline & & 1 & 5 & 10 & 15 & \\
\hline \multirow{3}{*}{ Brix } & HADP & $1.30 \pm 0.0^{2(b 3)(4)}$ & $1.80 \pm 0.00^{\mathrm{aB}}$ & $1.13 \pm 0.06^{\mathrm{bC}}$ & $1.67 \pm 0.21^{\mathrm{aB}}$ & $24.83^{* * *}$ \\
\hline & CADP & $2.00 \pm 0.00^{\mathrm{aA}}$ & $1.70 \pm 0.00^{\mathrm{cC}}$ & $1.20 \pm 0.00^{\mathrm{dB}}$ & $1.83 \pm 0.12^{\mathrm{bB}}$ & $107.00^{* * *}$ \\
\hline & FDP & $1.83 \pm 0.06^{\mathrm{dB}}$ & $2.43 \pm 0.06^{\mathrm{bA}}$ & $2.20 \pm 0.00^{\mathrm{cA}}$ & $2.87 \pm 0.15^{\mathrm{aA}}$ & $74.96^{* * *}$ \\
\hline \multicolumn{2}{|c|}{ F-value } & $361.00^{* * 5}$ & $427.00^{* \star *}$ & $964.00^{* * *}$ & $47.54^{* * *}$ & \\
\hline
\end{tabular}

\footnotetext{
${ }^{1)} \mathrm{HADP}$, hot air-drying paprika; CADP, cold air-drying paprika; FDP, freeze-drying paprika.

${ }^{2)}$ All value are expressed as Mean $\pm \mathrm{SD}$ of triplicate determinations.

3)ad- Means with different superscript in the same column are significantly different $(\mathrm{p}<0.05)$ by Duncan's multiple range test.

${ }^{4) A-D}$ Means with different superscript in the same row are significantly different $(\mathrm{p}<0.05)$ by Duncan's multiple range test.

${ }^{* * * *} \mathrm{p}<0.001$
} 
수록 당도는 다소 높아졌다. $\operatorname{Kim}$ 등(22)이 연구한 전처리 조건 및 건조방법에 따른 건조대추의 품질특성 연구결과에 서 건조방법에 따른 당도의 변화는 수분 손실에 따라 과실 내부의 고형분 함량이 증대된다는 결과로 미루어 볼 때 노란 파프리카의 당도 변화도 수분함량 변화에 따른 차이의 결과로 사료된다.

\section{산도 변화}

건조방법을 달리한 노란 파프리카의 저장기간 중 산도 변화에 대한 결과는 Table 4 와 같다. 노란 파프리카의 산도 는 저장 1 일 차의 경우 $\mathrm{HADP}$ 에서는 $1.92 \%, \mathrm{CADP}$ 에서 $3.24 \%, \mathrm{FDP}$ 에서는 $3.54 \%$ 으로 노란 파프리카의 산도는 $\mathrm{FDP}>\mathrm{CADP}>\mathrm{HADP}$ 순이었다. 저장 5 일 차의 경우 산도는 $\mathrm{HADP}$ 에서 $4.50 \%$, $\mathrm{CADP}$ 에서 $3.87 \%$, FDP에서는 $7.23 \%$ 으 로 저장 1 일 차에 비해 모든 군에서 산도는 증가함을 보였으 며, $\mathrm{HADP}$ 와 FDP에서는 1 일 차에 비해 두배 이상의 높은 산도를 보였다. 저장 10 일 차에서는 $\mathrm{HADP}$ 에서는 $4.59 \%$, $\mathrm{CADP}$ 에서 $4.47 \%, \mathrm{FDP}$ 에서는 $6.30 \%$ 으로 $\mathrm{HADP}$ 와 $\mathrm{CADP}$ 에서는 저장 5 일 차보다 산도는 증가함을 보였으나, $\mathrm{FDP}$ 에 서는 감소함을 보였다. 저장 15 일 차 산도의 변화는 $\mathrm{HADP}$ 에서는 $3.39 \%, \mathrm{CADP}$ 에서 $3.63 \%, \mathrm{FDP}$ 에서는 $7.20 \%$ 이었으 며, 저장 10 일 차에 비해 $\mathrm{HADP}$ 와 $\mathrm{CADP}$ 에서는 산도가 감소함을 보였고, $\mathrm{FDP}$ 에서는 산도가 증가함을 보였다. Moon(23)이 연구한 연잎분말을 첨가한 청포묵의 품질을 연구한 결과에서 $\mathrm{pH}$ 가 높을 경우 산도는 낮은 값을 보인 결과와 비교해 보면 본 연구결과와 유사한 결과를 보였다. 건조방법에 따른 노란 파프리카의 저장기간의 산도변화는 저장 1 일 차와 저장 5 일 차, 10 일 차, 15 일 차의 유의적 차이 $(\mathrm{p}<0.01)$ 가 있었으며, $\mathrm{CADP}$ 에서 다른 파프리카 군에 비해 저장기간동안 산도 변화의 증가폭이 적어 저장효과가 있음을 알 수 있었다.

\section{색도 변화}

건조방법을 달리한 노란 파프리카의 저장기간 중 색도 변화에 대한 결과는 Table 5 와 같다. 파프리카의 $\mathrm{L}$ 값(명도)
파프리카 처리군에 비해 명도는 더 높았다. 파프리카 외피 의 명도는 저장기간이 길어질수록 $\mathrm{HADP}$ 에서는 감소함을 보였고, $\mathrm{CADP}$ 와 $\mathrm{FDP}$ 에서는 저장 10 일 차까지 명도는 감소 함을 보이다가 저장 15 일 차 증가하였다.

파프리카 내피(inside)의 명도는 저장 1 일 차의 경우 HADP에서는 58.77, $\mathrm{CADP}$ 에서 59.78, FDP에서는 76.38으 로 파프리카 외피의 명도와 동일하게 $\mathrm{FDP}$ 에서 명도는 더 높았다. 저장기간이 길어질수록 명도는 $\mathrm{HADP}$ 가 저장 5일 차에서 감소함을 보이다 저장 10 일 차에서 다소 증가함을 보였으며, 저장 15 일 차에서 다시 감소함을 보였다. CADP 에서는 저장기간이 길어질수록 명도는 감소함을 보였고, $\mathrm{FDP}$ 에서는 저장 10 일 차까지 명도는 감소함을 보이다 15 일 차 증가함을 보였다.

파프리카의 $\mathrm{a}$ 값(적색도)은 외피에서 저장 1 일 차의 경우 HADP에서는 12.13, CADP에서 13.04, FDP에서는 13.46으 로 FDP에서 다른 파프리카 군에 비해 적색도는 다소 높았 다. 저장기간이 길어질수록 적색도는 $\mathrm{HADP}$ 에서는 저장 5 일 차의 경우 증가함을 보이다 감소함을 보였고, $\mathrm{CADP}$ 에 서는 저장기간이 길어질수록 적색도는 증가하였다.

파프리카의 내피의 적색도는 저장 1 일 차의 경우 $\mathrm{HADP}$ 에서는 12.14, $\mathrm{CADP}$ 에서 12.36, FDP에서는 5.71으로 $\mathrm{CADP}$ 에서 적색도는 높았고, $\mathrm{FDP}$ 에서 적색도는 낮았다. 저장기간이 길어질수록 내피의 $\mathrm{HADP}$ 에서는 증가함을 보 이다 감소하고 저장 15 일 차에서 증가함을 보였다. CADP 에서는 저장기간이 길어질수록 적색도는 증가하였고, $\mathrm{FDP}$ 에서는 저장기간이 길어질수록 증가함을 보이다가 저장 15 일 차에 다소 감소하였다.

파프리카 $\mathrm{b}$ 값(황색도)은 외피에서 저장 1 일 차의 경우 HADP에서는 40.03, CADP에서 44.34, FDP에서는 64.96으 로 FDP에서 다른 파프리카 군에 비해 황색도는 높았다. 저장기간이 길어질수록 파프리카 외피의 황색도는 $\mathrm{HADP}$ 와 $\mathrm{CADP}$ 에서는 감소함을 보였고, $\mathrm{FDP}$ 에서는 저장기간이 길어질수록 감소함을 보이다가 저장 15 일 차에 다소 증가 하였다.

Table 4. Changes in the acidity of yellow paprika according to drying methods

\begin{tabular}{|c|c|c|c|c|c|c|}
\hline \multirow{2}{*}{\multicolumn{2}{|c|}{ Samples ${ }^{1)}$}} & \multicolumn{4}{|c|}{ Storage period (day) } & \multirow{3}{*}{$\frac{\text { F-value }}{12.48^{* *}}$} \\
\hline & & \multirow{2}{*}{$\frac{1}{1.92 \pm 0.10^{2(b 3)(B 4)}}$} & \multirow{2}{*}{$\begin{array}{c}5 \\
4.50 \pm 0.36^{\mathrm{B}}\end{array}$} & \multirow{2}{*}{$\begin{array}{c}10 \\
4.59 \pm 0.39^{a B}\end{array}$} & \multirow{2}{*}{$\begin{array}{c}15 \\
3.39 \pm 0.37^{\mathrm{aB}}\end{array}$} & \\
\hline & HADP & & & & & \\
\hline \multirow{2}{*}{$(\%)$} & CADP & $3.24 \pm 0.41^{\mathrm{bA}}$ & $3.87 \pm 0.24^{\mathrm{aB}}$ & $4.47 \pm 0.42^{\mathrm{aB}}$ & $3.63 \pm 0.95^{\mathrm{bB}}$ & $10.29^{* *}$ \\
\hline & FDP & $3.54 \pm 0.61^{\mathrm{bA}}$ & $7.23 \pm 0.53^{\mathrm{aA}}$ & $6.30 \pm 0.48^{\mathrm{aA}}$ & $7.20 \pm 0.39^{\mathrm{aA}}$ & $11.27^{* *}$ \\
\hline \multicolumn{2}{|c|}{ F-value } & $12.02^{* 5_{5}}$ & $61.82^{* * *}$ & $17.04^{* *}$ & $34.03^{* *}$ & \\
\hline
\end{tabular}

\footnotetext{
${ }^{1)} \mathrm{HADP}$, hot air-drying paprika; CADP, cold air-drying paprika; FDP, freeze-drying paprika.

${ }^{2)}$ All value are expressed as Mean $\$$ SD of triplicate determinations.

3)a-d Means with different superscript in the same column are significantly different $(p<0.05)$ by Duncan's multiple range test.

${ }^{4) A-D}$ Means with different superscript in the same row are significantly different $(\mathrm{p}<0.05)$ by Duncan's multiple range test.

${ }^{5 * *} \mathrm{p}<0.01, \stackrel{* * *}{\mathrm{p}}<0.001$.
} 
Table 5. Changes in the color of yellow paprika according to drying methods

\begin{tabular}{|c|c|c|c|c|c|c|c|}
\hline & \multirow{2}{*}{ Samples ${ }^{1)}$} & & \multicolumn{4}{|c|}{ Storage period (day) } & \multirow{2}{*}{ F-value } \\
\hline & & & 1 & 5 & 10 & 15 & \\
\hline \multirow{12}{*}{ Outside } & \multirow{3}{*}{$\mathrm{L}$} & HADP & $63.26 \pm 1.4^{2) \mathrm{a} 33 \mathrm{NS} 4)}$ & $49.43 \pm 0.69^{(\mathrm{CS})}$ & $53.28 \pm 0.19^{\mathrm{bB}}$ & $33.67 \pm 0.78^{\mathrm{dC}}$ & $134.33^{* * *}$ \\
\hline & & CADP & $59.49 \pm 7.48^{\mathrm{aNS}}$ & $52.75 \pm 0.46^{\mathrm{abB}}$ & $44.08 \pm 0.65^{\mathrm{cC}}$ & $47.78 \pm 0.13^{\mathrm{bCB}}$ & $9.42^{* *}$ \\
\hline & & FDP & $70.31 \pm 2.64^{\mathrm{aNS}}$ & $69.19 \pm 0.07^{\mathrm{aA}}$ & $55.39 \pm 0.15^{\mathrm{cA}}$ & $61.00 \pm 0.27^{\mathrm{bA}}$ & $84.58^{* * *}$ \\
\hline & \multicolumn{2}{|c|}{ F-value } & $4.17^{\mathrm{ns}}$ & $98.34^{* 6)}$ & $672.13^{\text {*** }}$ & $5250.94^{* * *}$ & \\
\hline & \multirow{3}{*}{ a } & HADP & $12.13 \pm 0.67^{\mathrm{cNS}}$ & $16.99 \pm 0.37^{\mathrm{aB}}$ & $15.32 \pm 0.20^{\mathrm{bB}}$ & $14.46 \pm 0.75^{\mathrm{bB}}$ & $41.05^{* * *}$ \\
\hline & & CADP & $13.04 \pm 3.05^{\mathrm{bNS}}$ & $19.03 \pm 0.17^{\mathrm{aA}}$ & $19.82 \pm 0.65^{\mathrm{aA}}$ & $20.83 \pm 0.13^{\mathrm{aA}}$ & $14.85^{*}$ \\
\hline & & FDP & $13.46 \pm 0.41^{\mathrm{bNS}}$ & $14.73 \pm 0.13^{\mathrm{abC}}$ & $14.50 \pm 0.11^{\mathrm{abC}}$ & $15.67 \pm 1.37^{a B}$ & $4.79^{*}$ \\
\hline & & & $0.41^{\mathrm{ns}}$ & $226.62^{* * *}$ & $157.30^{* * *}$ & $39.21^{* * *}$ & \\
\hline & \multirow{3}{*}{$\mathrm{b}$} & HADP & $40.03 \pm 0.52^{\mathrm{bB}}$ & $26.98 \pm 1.77^{\mathrm{cC}}$ & $44.28 \pm 3.64^{\mathrm{aA}}$ & $7.84 \pm 0.46^{\mathrm{dC}}$ & $191.04^{* * *}$ \\
\hline & & CADP & $44.34 \pm 12.57^{7^{\mathrm{B}}}$ & $32.52 \pm 1.28^{\mathrm{abB}}$ & $25.99 \pm 2.98^{\mathrm{bC}}$ & $23.28 \pm 1.13^{\mathrm{bB}}$ & $6.21^{*}$ \\
\hline & & FDP & $64.96 \pm 6.33^{\mathrm{aA}}$ & $58.12 \pm 0.05^{\mathrm{bA}}$ & $35.14 \pm 0.22^{\mathrm{dB}}$ & $44.05 \pm 1.47^{\mathrm{cA}}$ & $51.52^{* * *}$ \\
\hline & & & $8.05^{*}$ & $523.25^{* * *}$ & $33.90^{* * *}$ & $811.79^{* * *}$ & \\
\hline \multirow{12}{*}{ Inside } & \multirow{3}{*}{$\mathrm{L}$} & HADP & $58.77 \pm 3.52^{\mathrm{aB}}$ & $49.25 \pm 0.07^{\mathrm{cB}}$ & $54.50 \pm 0.87^{\mathrm{bA}}$ & $34.33 \pm 0.61^{\mathrm{dC}}$ & $101.34^{* * *}$ \\
\hline & & CADP & $59.78 \pm 8.43^{\mathrm{aB}}$ & $48.33 \pm 1.52^{\mathrm{bB}}$ & $39.29 \pm 1.26^{\mathrm{cB}}$ & $38.11 \pm 0.57^{\mathrm{CB}}$ & $16.03^{* *}$ \\
\hline & & FDP & $76.38 \pm 2.47^{\mathrm{aA}}$ & $76.07 \pm 0.16^{\mathrm{aA}}$ & $55.25 \pm 0.83^{\mathrm{cA}}$ & $65.95 \pm 1.12^{\mathrm{bA}}$ & $148.87^{* * *}$ \\
\hline & \multicolumn{2}{|c|}{ F-value } & $9.82^{*}$ & $960.13^{* * *}$ & $246.19^{* * *}$ & $1361.71^{* * *}$ & \\
\hline & \multirow{3}{*}{$\mathrm{a}$} & HADP & $12.14 \pm 1.05^{\mathrm{dA}}$ & $19.10 \pm 0.05^{\mathrm{aA}}$ & $15.08 \pm 0.51^{\mathrm{cB}}$ & $17.02 \pm 0.75^{\mathrm{bB}}$ & $54.70^{* * *}$ \\
\hline & & CADP & $12.36 \pm 4.06^{\mathrm{cA}}$ & $19.62 \pm 2.10^{\mathrm{bA}}$ & $22.56 \pm 0.45^{\mathrm{abA}}$ & $24.73 \pm 0.40^{\mathrm{aA}}$ & $16.46^{* *}$ \\
\hline & & FDP & $5.71 \pm 2.26^{\mathrm{bB}}$ & $6.54 \pm 0.04^{6 \mathrm{~B}}$ & $11.62 \pm 0.55^{\mathrm{aC}}$ & $10.69 \pm 0.30^{\mathrm{aC}}$ & $18.87^{* *}$ \\
\hline & \multicolumn{2}{|c|}{ F-value } & $5.67^{*}$ & $112.23^{* * *}$ & $370.47^{* \star *}$ & $553.06^{* * *}$ & \\
\hline & \multirow{3}{*}{$\mathrm{b}$} & HADP & $39.61 \pm 4.56^{\mathrm{bNS}}$ & $39.05 \pm 0.44^{\mathrm{bB}}$ & $52.00 \pm 2.59^{\mathrm{aA}}$ & $12.85 \pm 1.84^{\mathrm{CC}}$ & $104.56^{* * *}$ \\
\hline & & CADP & $48.52 \pm 16.26^{\mathrm{aNS}}$ & $36.06 \pm 6.90^{\mathrm{abB}}$ & $27.97 \pm 2.40^{\mathrm{bC}}$ & $24.41 \pm 1.49^{\mathrm{bB}}$ & $4.29^{*}$ \\
\hline & & FDP & $53.81 \pm 2.18^{\mathrm{aNS}}$ & $51.73 \pm 0.22^{\mathrm{aA}}$ & $34.51 \pm 1.18^{\mathrm{cB}}$ & $40.89 \pm 1.10^{\mathrm{bA}}$ & $135.20^{* * *}$ \\
\hline & \multicolumn{2}{|c|}{ F-value } & $1.60^{\mathrm{ns}}$ & $13.02^{* *}$ & $99.86^{* * *}$ & $262.35^{\text {***}}$ & \\
\hline
\end{tabular}

${ }^{1)} \mathrm{HADP}$, hot air-drying paprika; CADP, cold air-drying paprika; FDP, freeze-drying paprika.

${ }^{2)}$ All value are expressed as Mean \pm SD of triplicate determinations.

3)a-d Means with different superscript in the same column are significantly different $(p<0.05)$ by Duncan's multiple range test.

${ }^{4)} \mathrm{NS}$, none significant.

${ }^{5) A-D}$ Means with different superscript in the same row are significantly different $(p<0.05)$ by Duncan's multiple range test.

6) $\mathrm{p}<0.05,{ }^{* *} \mathrm{p}<0.01,{ }^{* * *} \mathrm{p}<0.001$.

파프리카의 내피의 황색도는 저장 1 일 차의 경우 HADP 에서는 39.61, $\mathrm{CADP}$ 에서 48.52, $\mathrm{FDP}$ 에서는 53.81으로 FDP 에서 황색도는 높았고, $\mathrm{HADP}$ 에서 황색도는 낮았다. 저장 기간이 길어질수록 파프리카 내피의 황색도는 $\mathrm{HADP}$ 와 $\mathrm{CADP}$ 에서는 감소함을 보였고, $\mathrm{FDP}$ 에서는 저장기간이 길 어질수록 감소함을 보이다가 저장 15 일 차에 다소 증가하 였다.

$\operatorname{Kim}$ 등(24)이 연구한 건조방법과 제분방법에 따른 마의 가공적성 연구에서 동결건조 및 냉풍건조 마보다 열풍건조 한 마에서 백색도가 낮은 것은 건조과정 중에 polyphenol oxidase와 같은 효소에 의한 효소적 갈변과 비효소적 갈변 이 복합적 작용에 의해 일어난 갈변 현상이 진행된 것으로 판단하였다. 이와 같이 노란 파프리카의 저장기간에 따른
색도의 변화에서 $\mathrm{FDP}$ 가 $\mathrm{HADP}$ 와 $\mathrm{CADP}$ 보다 저장기간에 따른 명도 적색도, 황색도의 변화가 가장 적게 나타나 파프 리카 가공 식품을 개발 할 때 동결건조 방법을 활용한다면 좀 더 상품성이 뛰어난 제품이 개발이 될 것으로 생각된다.

\section{물성 변화}

건조방법을 달리한 노란 파프리카의 저장기간 중 물성 변화에 대한 결과는 Table 6과 같다. 강도(strongness)는 저 장 1 일 차에서 $\mathrm{HADP}$ 는 $0.25 \mathrm{~kg} / \mathrm{cm}^{2}, \mathrm{CADP}$ 에서 0.17 $\mathrm{kg} / \mathrm{cm}^{2}, \mathrm{FDP}$ 에서는 $1.61 \mathrm{~kg} / \mathrm{cm}^{2}$ 으로 FDP에서 강도가 높았 으며, 저장기간이 길어질수록 강도는 모든군에서 대체적으 로 감소함을 보였다.

경도(hardness)는 저장 1 일 차에서 $\mathrm{HADP}$ 는 $10.23 \mathrm{~kg} / \mathrm{cm}^{2}$, 
Table 6. Changes in the texture of yellow paprika according to drying methods

\begin{tabular}{|c|c|c|c|c|c|c|}
\hline \multirow{2}{*}{\multicolumn{2}{|c|}{ Samples ${ }^{1)}$}} & \multicolumn{4}{|c|}{ Storage period (day) } & \multirow{3}{*}{$\begin{array}{c}\text { F-value } \\
21.75^{* * *}\end{array}$} \\
\hline & & 1 & 5 & 10 & 15 & \\
\hline \multirow{3}{*}{$\begin{array}{c}\text { Strongness } \\
\left(\mathrm{kg} / \mathrm{cm}^{2}\right)\end{array}$} & HADP & $0.25 \pm 0.04^{2)(3) B 4}$ & $0.13 \pm 0.00^{\mathrm{bB}}$ & $0.15 \pm 0.02^{\mathrm{bB}}$ & $0.11 \pm 0.02^{\mathrm{bB}}$ & \\
\hline & CADP & $0.17 \pm 0.01^{\mathrm{bB}}$ & $0.08 \pm 0.00^{\mathrm{dC}}$ & $0.20 \pm 0.03^{\mathrm{aA}}$ & $0.14 \pm 0.01^{\mathrm{cB}}$ & $40.78^{* * *}$ \\
\hline & FDP & $1.61 \pm 0.18^{\mathrm{aA}}$ & $0.38 \pm 0.02^{\mathrm{bA}}$ & $0.18 \pm 0.02^{\mathrm{cAB}}$ & $0.20 \pm 0.04^{\mathrm{bcA}}$ & $171.03^{* * *}$ \\
\hline \multicolumn{2}{|c|}{ F-value } & $184.47^{* \star * 5)}$ & $425.69^{* * *}$ & $5.72^{* *}$ & $11.18^{* *}$ & \\
\hline \multirow{3}{*}{$\begin{array}{l}\text { Hardness } \\
\left(\mathrm{kg} / \mathrm{cm}^{2}\right)\end{array}$} & HADP & $10.23 \pm 1.14^{\mathrm{aB}}$ & $2.88 \pm 0.00^{\mathrm{bC}}$ & $3.70 \pm 0.40^{\mathrm{bB}}$ & $3.52 \pm 0.59^{\mathrm{bNS} 6)}$ & $78.91^{* * *}$ \\
\hline & CADP & $17.29 \pm 2.03^{\mathrm{aA}}$ & $10.56 \pm 0.00^{\mathrm{bA}}$ & $3.69 \pm 0.15^{\mathrm{cB}}$ & $2.84 \pm 1.17^{\mathrm{cNS}}$ & $99.20^{* * *}$ \\
\hline & FDP & $16.13 \pm 1.76^{\mathrm{aA}}$ & $5.00 \pm 1.18^{\mathrm{bB}}$ & $3.00 \pm 0.38^{\mathrm{bA}}$ & $3.60 \pm 0.50^{\mathrm{bNS}}$ & $94.52^{* * *}$ \\
\hline \multicolumn{2}{|c|}{ F-value } & $15.14^{* *}$ & $104.42^{* * *}$ & $5.20^{*}$ & $0.78^{\mathrm{ns}}$ & \\
\hline \multirow{3}{*}{$\begin{array}{c}\text { Cohesivenes } \\
(\%)\end{array}$} & HADP & $102.70 \pm 5.25^{\mathrm{aA}}$ & $104.49 \pm 2.87^{a B}$ & $93.96 \pm 0.88^{\mathrm{bNS}}$ & $100.83 \pm 4.0^{\mathrm{aNS}}$ & $5.06^{*}$ \\
\hline & CADP & $103.90 \pm 1.88^{\mathrm{bA}}$ & $130.86 \pm 13.3^{\mathrm{aA}}$ & $95.34 \pm 2.90^{\mathrm{bNS}}$ & $96.43 \pm 1.13^{\mathrm{bNS}}$ & $17.38^{* \star}$ \\
\hline & FDP & $77.22 \pm 6.01^{\mathrm{bB}}$ & $92.98 \pm 2.36^{\mathrm{aB}}$ & $99.29 \pm 4.14^{\mathrm{a} N S}$ & $94.58 \pm 0.99^{\mathrm{a} S \mathrm{SS}}$ & $3.58^{* *}$ \\
\hline \multicolumn{2}{|c|}{ F-value } & $30.45^{* *}$ & $17.80^{* *}$ & $2.85^{\mathrm{ns}}$ & $5.10^{\mathrm{ns}}$ & \\
\hline \multirow{3}{*}{$\begin{array}{c}\text { Springiness } \\
(\%)\end{array}$} & HADP & $166.67 \pm 28.87^{\mathrm{nsA}}$ & $160.61 \pm 10.5^{\mathrm{nsB}}$ & $141.74 \pm 9.9^{\mathrm{nNSS}}$ & $155.16 \pm 4.51^{\mathrm{nsA}}$ & $1.28^{\mathrm{ns}}$ \\
\hline & CADP & $134.92 \pm 6.74^{\mathrm{cbA}}$ & $166.81 \pm 1.52^{\mathrm{aA}}$ & $122.05 \pm 1.78^{\mathrm{cNS}}$ & $143.59 \pm 12.42^{\mathrm{bA}}$ & $20.78^{* * *}$ \\
\hline & FDP & $98.67 \pm 6.11^{\mathrm{bB}}$ & $107.28 \pm 4.53^{\mathrm{bB}}$ & $126.51 \pm 14.26^{\mathrm{aNS}}$ & $111.75 \pm 8.39^{\mathrm{abB}}$ & $4.91^{*}$ \\
\hline \multicolumn{2}{|c|}{ F-value } & $11.37^{* *}$ & $72.46^{* * *}$ & $3.15^{\mathrm{ns}}$ & $18.58^{* *}$ & \\
\hline \multirow{3}{*}{$\begin{array}{l}\text { Chewiness } \\
\text { (g) }\end{array}$} & HADP & $8.18 \pm 0.61^{\mathrm{aB}}$ & $9.40 \pm 0.26^{\mathrm{aB}}$ & $9.7 \pm 1.34^{\mathrm{aB}}$ & $8.06 \pm 1.71^{\mathrm{aB}}$ & 1.64 \\
\hline & CADP & $12.13 \pm 0.75^{\mathrm{aB}}$ & $7.85 \pm 0.80^{\mathrm{bB}}$ & $13.64 \pm 1.03^{\mathrm{aA}}$ & $9.32 \pm 1.08^{\mathrm{bB}}$ & $24.07^{* * *}$ \\
\hline & FDP & $38.99 \pm 3.57^{\mathrm{cA}}$ & $25.10 \pm 1.31^{\mathrm{bA}}$ & $12.88 \pm 0.54^{\mathrm{aA}}$ & $13.86 \pm 2.25^{\mathrm{aA}}$ & $90.16^{* * *}$ \\
\hline \multicolumn{2}{|c|}{ F-value } & $185.35^{* * *}$ & $337.43^{* * *}$ & $12.48^{* *}$ & $9.18^{*}$ & \\
\hline \multirow{3}{*}{$\begin{array}{l}\text { Brittleness } \\
\text { (g) }\end{array}$} & HADP & $13.53 \pm 1.42^{\mathrm{nSC}}$ & $15.12 \pm 1.34^{\mathrm{nsB}}$ & $13.66 \pm 0.92^{\text {nsB }}$ & $12.54 \pm 2.93^{\text {nNS }}$ & $1.02^{\mathrm{ns}}$ \\
\hline & CADP & $16.36 \pm 1.26^{\mathrm{aB}}$ & $12.13 \pm 0.07^{\mathrm{bA}}$ & $16.63 \pm 10.4^{\mathrm{aA}}$ & $13.30 \pm 0.56^{\mathrm{bSS}}$ & $20.07^{* * *}$ \\
\hline & FDP & $38.33 \pm 1.12^{\mathrm{aA}}$ & $26.95 \pm 2.45^{\mathrm{bB}}$ & $16.27 \pm 1.54^{\mathrm{cA}}$ & $15.37 \pm 1.55^{\mathrm{cNS}}$ & $115.90^{* * *}$ \\
\hline \multicolumn{2}{|c|}{ F-value } & $340.69^{* * *}$ & $70.93^{* * *}$ & $5.53^{*}$ & $1.71^{\text {ns }}$ & \\
\hline
\end{tabular}

${ }^{1}$ HADP, hot air-drying paprika; CADP, cold air-drying paprika; FDP, freeze-drying paprika.

${ }^{2}$ All value are expressed as Mean $\pm \mathrm{SD}$ of triplicate determinations.

3)a-d Means with different superscript in the same column are significantly different $(p<0.05)$ by Duncan's multiple range test.

${ }^{4) A-D}$ Means with different superscript in the same row are significantly different $(p<0.05)$ by Duncan's multiple range test.

${ }^{5}{ }^{*} \mathrm{p}<0.05,{ }^{* *} \mathrm{p}<0.01,{ }^{* * *} \mathrm{p}<0.001$

${ }^{6} \mathrm{NS}$, none significant.

$\mathrm{CADP}$ 에서 $17.29 \mathrm{~kg} / \mathrm{cm}^{2}, \mathrm{FDP}$ 에서는 $16.13 \mathrm{~kg} / \mathrm{cm}^{2}$ 으로 $\mathrm{CADP}$ 에서 경도는 다른 파프리카 군에 비해 높았으며, 저장 기간이 길어질수록 경도는 모든군에서 대체적으로 감소함 을 보였으며, $\mathrm{CADP}$ 에서 경도의 감소는 더 크게 나타났다.

응집성(cohesiveness)은 저장 1일 차에서 $\mathrm{HADP}$ 는 $102.70 \%$, CADP에서 $103.90 \%$, FDP에서는 $77.22 \%$ 으로 $\mathrm{HADP}$ 와 $\mathrm{CADP}$ 에서 FDP보다 응집성은 높았으며, 저장기 간이 길어질수록 $\mathrm{HADP}$ 에서는 응집성이 감소함을 보이다 저장 15 일 차에 다소 증가함을 보였으며, $\mathrm{CADP}$ 에서는 응 집성이 다소 감소함을 보였고, $\mathrm{FDP}$ 에서는 저장기간이 길어 질수록 응집성이 다소 증가함을 보였다.

탄력성(springiness)은 저장 1 일 차에서 $\mathrm{HADP}$ 는 $166.67 \%, \mathrm{CADP}$ 에서 $134.92 \%, \mathrm{FDP}$ 에서는 $98.67 \%$ 으로
$\mathrm{HADP}$ 에서 다른 파프리카 처리군에 비해 탄력성은 높았 으며, 저장 15 일 차에는 $\mathrm{HADP}$ 는 다소 감소하였고, 다른 파프리카 처리군에서는 증가함을 보였다.

씹음성(chewiness)은 저장 1 일 차 $\mathrm{HADP}$ 는 $8.18 \mathrm{~g}, \mathrm{CADP}$ 에서 $12.13 \mathrm{~g}$, FDP에서는 $38.99 \mathrm{~g}$ 으로 FDP에서 씹음성은 가장 높았다. 저장기간이 길어질수록 씹음성은 $\mathrm{HADP}$ 에서 는 증가함을 보이다 저장 15 일 차에 감소함을 보였으며, $\mathrm{CADP}$ 에서는 씹음성은 감소함을 보이다 증가함을 보이고 저장 15 일 차에 다시 감소하였다. $\mathrm{CADP}$ 에서는 저장기간이 길어질수록 씹음성은 감소함을 보였다.

깨짐성(brittleness)은 저장 1 일 차에서 $\mathrm{HADP}$ 는 $13.53 \mathrm{~g}$, $\mathrm{CADP}$ 에서 $16.36 \mathrm{~g}$, FDP에서는 $38.33 \mathrm{~g}$ 으로 FDP에서 깨짐 성은 가장 높았으며, $\mathrm{HADP}$ 에서 깨짐성은 가장 낮았다. 저 
장기간이 길어질수록 깨짐성은 $\mathrm{HADP}$ 에서는 저장 5 일 차 에 증가함을 보이다 저장 10 일 차와 15 일 차에는 감소함을 보였으며, $\mathrm{CADP}$ 와 $\mathrm{FDP}$ 는 저장기간이 길어질수록 깨짐성 은 감소함을 보였다.

건조방법에 따른 노란 파프리카의 물성측정에서는 저장 기간이 길어질수록 경도, 강도, 응집성, 씹음성, 깨짐성은 대부분 파프리카 처리군에서 감소함을 보였고, 탄력성은 증가함을 보였다. 이는 노란 파프리카가 건조방법에 따라 건조에 의한 수축으로 조직이 치밀해지면서 파프리카의 조직감이 나빠지는 것으로 생각된다.

\section{총 균수 변화}

건조방법을 달리한 노란 파프리카의 저장기간 중 총 균 수 변화에 대한 결과는 Fig. 1과 같다. 저장 1 일 차에서 $\mathrm{HADP}$ 는 $4.90 \log \mathrm{CFU} / \mathrm{mL}, \mathrm{CADP}$ 에서 $5.26 \log \mathrm{CFU} / \mathrm{mL}$, $\mathrm{FDP}$ 에서는 $5.75 \log \mathrm{CFU} / \mathrm{mL}$ 으로 FDP에서 다른 파프리카 에 비해 총 균수는 높았다. 저장기간이 길어질수록 HADP 에서는 총 균수는 증가함을 보여 저장 15 일 차에는 6.97 $\log \mathrm{CFU} / \mathrm{mL}$ 이었다. $\mathrm{CADP}$ 와 $\mathrm{FDP}$ 는 저장 10 일 차 총 균수 는 각각 $7.39,7.18 \log \mathrm{CFU} / \mathrm{mL}$ 으로 증가함을 보였으며, 저장 15 일 차에는 총 균수가 증가하여 각각 TNTC(too numerous to count)로 나타났다. 미생물은 농산물이나 식품 의 생산과 유통 과정 중 다양한 외부 환경요인에 따라 오 염 - 증식 · 사멸을 반복하며, 생육에 유리한 환경에 노출될 때는 식중독 사고를 일으킬 수 있는 수준까지 증식할 수 있다(25). Bae 등(26)의 연구에서 일반농산물에서 총 균수 가 평균 3.7-8.0 $\log \mathrm{CFU} / \mathrm{mL}$ 로 높은 수준으로 검출되었으 며, Hong 등(27)의 연구에서는 채소류 총균수가 2.8-9.4 log $\mathrm{CFU} / \mathrm{mL}$ 범위로 검출되었다. 이들 결과와 비교했을 때 본 연구의 건조방법에 따른 파프리카 처리군들은 저장 초기 총 균수의 오염도는 낮은 수준이었으며, 저장기간동안 오

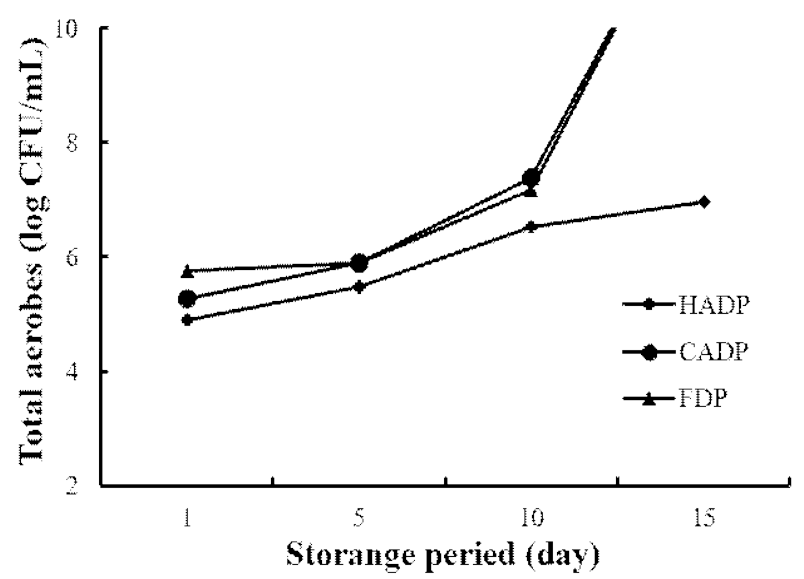

Fig. 1. Changes in the total aerobes of yellow paprika according to drying methods.

HADP, hot air-drying paprika; CADP, cold air-drying paprika; FDP, freeze-drying paprika.
염도를 낮출 수 있는 방법에 대해 추가적으로 연구가 진행 되어야 할 것으로 생각된다.

\section{요 약}

본 연구는 노란 파프리카의 건조 방법을 달리하여 저장 기간에 따른 품질특성 변화를 연구하고, 노란 파프리카의 다양한 가공식품개발을 위한 기초자료로 이용하고자 하였 다. 건조 파프리카의 수분함량은 FDP에서 저장 1 일 차에서 $11.19 \%$ 이었고, 저장 15 일 차에는 $18.19 \%$ 으로 저장기간이 길어질수록 수분함량의 증가폭이 적었다. $\mathrm{pH}$ 변화는 저장 기간에 따라 약 $\mathrm{pH} 5$ 정도로 변화가 크게 없었으며, 당도 변화에서는 FDP에서 저장기간이 길어질수록 당도는 다소 높아짐을 보였다. 산도 변화에서는 FDP > CADP > HADP 순으로 저장기간이 길어질수록 모든 군에서 산도는 증가함 을 보였으며 $\mathrm{HADP}$ 에서 산도의 증가폭이 적게 나타났다. 색도 변화에서는 명도 $\mathrm{L}$ 값은 파프리카 외피와 내피에서 저장기간이 길어질수록 감소함을 보였으며, $\mathrm{FDP}$ 에서 $\mathrm{L}$ 값 이 더 높았다. $\mathrm{a}$ 값은 건조 파프리카 외피와 내피의 저장기 간에 따른 차이가 크게 없었으며, $\mathrm{b}$ 값은 $\mathrm{FDP}$ 의 외피와 내피에서 저장기간이 길어질수록 높았다. 물성측정 변화는 강도와 경도, 씹힘성, 깨짐성은 건조 파프리카 모든 군에서 저장기간이 길어질수록 감소함을 보였으며, $\mathrm{FDP}$ 에서 높았 다. 총 균수 변화는 $\mathrm{HADP}$ 에서 저장 1 일 차에 $4.90 \mathrm{log}$ $\mathrm{CFU} / \mathrm{mL}$ 으로 가장 낮았고, 저장기간이 길어질수록 증가하 였으나 다른 파프리카 군에 비해 낮았다. 따라서 건조방법 에 따른 노란 파프리카의 품질특성 연구는 건조된 노란 파프리카를 이용한 가공식품 및 건강식품의 개발에 기초자 료가 될 것으로 생각된다.

\section{감사의 글}

본 연구는 2015 대구한의대학교 기린연구년제 지원으로 수행되었으며, 이에 감사드립니다.

\section{References}

1. Yu YM, Youn YN, Choi IU, Lee YH (2011) Microbiological monitoring of paprika, and bacterial contamination levels with respect to storage temperature. Korean J Food Preserv, 18, 7-12

2. Kim SW, Kim JG, Kim SK, Choi SY, Youn UY, Lee SC (2014) Antioxidant and tyrosinase inhibitory activities of different parts from different cultivar paprika. J Basic 
Sci, 31, 33-44

3. Hwang JH, Jang MS (2001) Effect of paprika (Capsicum annuum L.) juice on the acceptability and quality of wet noodle ( I ). Korean J Soc Food Cookery Sci, 17, 373-379

4. Lee HD, Do JW, Han JH, An CG, Kweon OY, Kim YK, Yoon JB (2011) Allelism and molecular marker tests for genic male sterility in paprika cultivars. Kor J Hort Sci Technol, 29, 130-134

5. Jeong CH, Ko WH, Cho JR, Ahn CG, Shim KH (2006) Chemical components of Korean paprika according to cultivars. Korean J Food Preserv, 13, 43-49

6. Lee HS (2017) Antioxidant of extracts from paprika and characteristics of the dried paprika by drying methods. MS Thesis, Daegu Haany University, Korea, p 1-5

7. Park EY, Kang SG, Jeong CH, Choi SD, Shim KH (2009) Quality characteristics of Yanggaeng added with paprika powder. J Agric Life Sci, 43, 37-43

8. Minguez-Mosquera MI, Perez-Galvez A, GarridoFernandez J (2000) Carotenoid concent of the varieties Jaranda and Jariza (Capsicum annuum L.) and response during the industrial slow drying and grinding steps in paprika processing. J Agric Food Chem, 48, 2972-2976

9. Perera CO, Yen GM (2007) Functional properties of carotenoids in human health. Int J Food Prop, 10, 201-230

10. Beltran J, Ghosh AK, Basu S (2007) Immunotherapy of tumors with neuroimmune ligand capsaicin. J Immunol, 178, 3260-3264

11. Jeong CH, Ko WH, Cho JR, Ahn CG, Shim KH (2006) Chemical components of Korean paprika according to cultivars. Korean J Food Preserv, 13, 43-49

12. Park JH, Kim CS, Noh, SK (2005) The effect of fresh paprika and paprika powder dried by far-infrared ray on inhibition of lipid oxidation in lard model system. Korean J Food Cookery Sci, 21, 475-481

13. Jeong CH, Ko WH, Cho JR, Ahn CG, Shim KH (2007) Preparation and characteristics of juice and jelly using Korean paprika. J Agric Life Sci, 41, 13-20

14. Jung JY, Choi MH, Hwang JH, Chung HJ (2004) Quality characteristics of Jeung-Pyun prepared with paprika juice. J Korean Soc Food Sci Nutr, 33, 869-874

15. Hong JH, Lee WY (2004) Quality characteristics of osmotic dehydrated sweet pumpkin by different drying methods. J Korean Soc Food Sci Nutr, 33, 1573-1579
16. Holdsworth SD (1971) Dehydration of food products. J Fd Technol, 6, 331-370

17. Christopher GJ (1997) Industrial drying of food. Blackie Academic and Professional, New York, NY, USA, p 1-6

18. Litvin S, Mannheim CH, Miltz J (1998) Dehydration of carrots by a combination of freeze drying, microwave heating and air or vaccum drying. J Food Eng, 36, 103-111

19. AOAC (2006) Offcial methods of analysis. $15^{\text {th }} \mathrm{ed}$, Association of official analytical chemists, Wahingtion DC, USA, p 210-219

20. Kim EJ, Kim TS, Kim MH (2013) Physicochemical and antioxidant properties of broccoli sprouts cultivated in the plant factory system. Korean J Food Culture, 28, 57-69

21. Park SJ, Choi YB, Ko JR, Rha YA, Lee HY (2014) Effects of drying methods on the quality and physiological activities of blueberry (Vaccinium ashei). Korean J Culinary Res, 20, 55-64

22. Kim JW, Lee SH, No HK, Hong JH, Park CS, Youn KS (2013) Effect of pretreatment and drying methods on quality and antioxidant activities of dried jujube (Zizyphus jujuba) fruit. J Korean Soc Food Sci Nutr, 42, 1242-1248

23. Moon JH (2013) Properties of regional lotus leaf and quality characteristics of cheongpomook with lotus powder. MS Thesis, Sejong University, Korea, p 34-35

24. Kim JY, Lee YC, Kim YC, Kim YB, Choi HW (2016) Research on processing properties of yam (Disocorea batatas) by drying methods and milling methods. Food Eng Prog, 20, 307-313

25. Park HJ, Min KJ, Park NY, Cho JI, Lee SH, Hwang IG, Heo JJ, Yoon KS (2013) Estimation on the consumption patterns of potentially hazardous foods with high consumer risk perception. Korean J Food Sci Technol, 45, 59-69

26. Bae YM, Hong YJ, Kang DH, Heu SG, Lee SY (2011) Microbial and pathogenic contamination of ready-to-eat fresh vegetables in Korea. Korean J Food Sci Technol, 43, 161-168

27. Hong CK, Seo YH, Choi CM, Hwang IS, Kim MS (2012) Microbial quality of fresh vegetables and fruits in seoul, Korea. J Fd Hyg Safety, 27, 24-29 